\title{
National Holiday Anomaly in Pakistani Stock market: Evidence from Karachi Stock Exchange KSE 100 Index
}

\author{
MUHAMMAD NABEEL \\ Abdul Wali Khan University, Mardan \\ muhammadnabeel089@gmail.com \\ QAZI SIKANDAR HAYAT \\ Lecturer, Abdul Wali Khan University, Mardan \\ qazi.hayat@awkum.edu.pk \\ MUHAMMAD DAUD ALI \\ Lecturer, University of Haripur, Haripur \\ daudalikhan725@gmail.com
}

\begin{abstract}
The study examined National Holiday Anomaly in Pakistani Stock Market. Specifically KSE 100 index data has been used by this study. The data of ten years (2004-2013) has been considered in order to check holiday anomaly. T-Test is used to check the presence of holiday anomaly. The study investigated holiday anomaly for each individual national holiday, each individual year and whole data sample. The results of all the three cases are insignificant suggesting the absence of National Holiday Anomaly in Pakistani Stock Market. The absence of such anomaly may be due to the nature of these holidays. As these holidays are not surrounded by any such activity which can affect the decision process of investors. Therefore based on the evidence provided by this examination the study can say that National Holiday Anomaly does not exist in Pakistani factors which need to be considered in order to understand Pakistani Stock Market in detail.
\end{abstract}

Keywords: National Holiday Anomaly, Efficient Market, Pakistani Stock Market, T-Test.

\section{Introduction}

One of the most important components of financial system of the capitalistic world is Stock markets. Financial assets such as stocks and bonds of joint stock companies, unit trusts, guilt age securities and other financial products are traded in Stock markets efficiently, systematically and by protecting investor's interests. Stock market acts as a bridge and enables institutions as well as individuals to contribute in country's wealth through their participation in the secondary market of the country. A well-regulated stock market decreases transactional costs and encourages fair pricing of securities. The stock market increases economic activity and increases economic growth as well. It is also a very good source of increasing employment in the country. The good performance of stock market is an indication of healthy economy. Due to the above mentioned reasons, stock traders keenly observe a slight movement in stock index which can influence their 
future profitability or assist them in evaluating their portfolios. The stock traders also observe the economy with great interest, in order to stay inform from any sudden change or incident that may affect their decisions of purchasing and selling stocks. The Efficient Market Hypothesis (EMH) presented by Fama (1970) suggests that stock markets work efficiently and that no one can earn abnormal returns. However certain studies have shown that there are inconsistent patterns in stock market which are commonly known as Calendar anomalies or Seasonality. Calendar anomaly or Seasonality is among one of the most puzzling topic in finance which has gained attention of the researchers during the last three decades. Many researchers have conducted research on calendar anomalies. Some of the famous Calendar anomalies include Day-of the-Week effect, Month-of-theYear effect, Weekly effect, Weekend effect, Ramadan effect, Pre-Holiday effect, PostHoliday effect and January effect etc. Among these anomalies one is the National Holiday anomaly. National Holiday anomaly refers to the phenomenon that mean stock returns are either high or low on the preceding day as well as high or low on following day of a holiday as compared to normal trading days. The holiday is a day which has at least one preceding day as trading day and one following day as trading day. The phenomenon of pre-holiday and post-holiday anomaly is against the weak form of efficient market hypothesis presented by Fama (1970) which postulates that; all relevant information available to the market participants should not allow them to earn abnormal returns.

Specifically, weak form of Efficient Market Hypothesis suggests that stock returns and stock prices should be distributed normally. In contrast, the evidence collected from studies shows that stock returns are not constant and suggests the presence of seasonal or calendar anomalies. The holiday effect is the abnormal returns around public holidays and this effect has been found in US and other developed and emerging markets. There is little research on the national holiday effect in Pakistan Stock Market and an important question is that how efficient Pakistani market is. In this study, the daily index data of KSE-100 index is used to analyze the existence and of holiday effect over time. The data is from 2004-2013 which includes 10 years daily data.

\subsection{Research Objectives}

- To investigate the presence of National Holiday Anomaly in Pakistani Stock Market

\subsection{Research Questions}

- Is there any National Holiday Anomaly present in Pakistani Stock Market?

\section{Literature Review}

The holiday effect refers to the behavior of investors before and after the holidays. Holiday can be defined as the day on which trading was supposed to take place but it did not. The definition of holiday does not only include weekend holidays but also all public holidays are included in it. It is a general observation that investors react very positively and they participate highly in trading before public holidays. That is why preholiday returns are usually higher as compared to post-holiday returns. The post-holiday returns are lower because investors are psychologically depressed or not very interested in taking part in trading activity. The existence of pre-holiday effect was found in seventeen markets for 65\% of sample by (Agrawal \& Tandon, 1994). Vergin and 
McGinnis (1999) studied the holiday effect for eight holidays on which stock exchange remained close. The holidays included Labor day (first Monday of May), President's day (third Monday of February), Easter, Independence day ( $4^{\text {th }}$ July), Thanksgiving day (fourth Thursday in November), Memorial day (last Monday of May), Christmas and new year's day. They took the data of 10 years (1987-1996) for finding the holiday effect. Vergin and McGinnis (1999) also examined holiday anomaly for both small and large corporations. They analyzed S\&P 500 and NYSE as proxy for small corporations and for large corporations they took NASDAQ and AMEX composite indices as their proxy. Their findings revealed that holiday effect is persistent in small corporations whereas in large corporations the holiday anomaly has disappeared. Furthermore they found that rate of return is not different for pre-holidays and normal days for S\&P and NYSE however for NASDAQ and AMEX the values were significantly high. The researchers also found that for all indices before 1987 pre-holiday returns were much higher which show that holiday effect is vanishing with the passage of time.

McGuinness (2005) studied Hang Seng Index of Hong Kong Stock Market for Chinese New Year holiday anomaly. The data was divided into two sample periods. First period was between 1995 and 2005 while the second period was between 1975 and 1995. Their results showed that stock returns show a rising trend prior to Chinese New Year holidays. Also the researchers suggested that this holiday anomaly is more stable as compared to other anomalies like day-of-the-week, month-of-the-year etc. Lakonishok and Smidt (1988) also studied holiday effect. They found holiday effect for eight public holidays which include Presidents' Day, Memorial Day, Independence Day, Labor Day, Thanksgiving Day, New Year Day, Christmas and Good Friday. Their findings strongly revealed the existence of holiday effect. They found that pre-holiday returns were approximately two to five times higher than returns before a weekend and twenty two times higher than normal days return. According to them pre-holiday returns were $63.9 \%$ positive. Ariel (1990) tested holiday effect for twenty years over the period of 1963 to 1982. The researcher examined holiday effect for eight holidays that is Presidents' Day, Thanksgiving Day, Labor Day, Independence Day, Memorial Day, Good Friday, Christmas and New Year's Day. He found that pre-holiday mean returns are on average nine to fourteen times higher than normal days mean returns. Ariel (1990) also checked pre-holidays stock returns at hourly basis. The result showed the same pattern of elevated returns over the day.

Marret and Worthington (2007) investigated holiday effect for Australian Stock Market. They used the daily stock returns at market as well as industry level. The data from September 1996 to November 2006 was also considered for small capitalization stocks. They also took eight public holidays for their investigation. The public holidays were Australia Day (26 ${ }^{\text {th }}$ January), Queen's Birthday, Christmas Day, Easter Friday and Easter Monday, ANZAC Day and Boxing Day. Their findings show that holiday effect is present all over the market and especially for small capitalization stocks. Cadsby and Ratner (1992) examined holiday effect in Australia, Canada, Japan and Hong Kong. They considered all local holidays, US holidays and joint holidays. The market indices data of each country was used for the period of 1962 to 1989. Their analysis revealed the presence of pre-holiday effect in all countries with highest return on the day prior to the 
holiday. The researchers also studied pre-holiday effect for European market but they didn't found any evidence in favor of pre-holiday effect in European Stock Markets. Cadsby and Ratner (1992) also studied Hong Kong stock market for Hang Seng Index for Chinese New Year holiday anomaly. The data contained data for the period of 1980 to 1989. The results strongly showed the presence of pre-holiday effect in Hong Kong Stock Market.Chong et al (2005) investigated pre-holiday effect for last three decades of twentieth century across three important markets of the world i.e. U.S, U.K and Hong Kong. Data Stream was used for extracting the data on daily stock index returns. U.S was represented by S\&P 500 index and FT 30 was used for the representation of U.K market. Hong Kong market was represented by Hang Seng index. The researchers studied the data from 1973 to 2003. The sample period for each of the three markets was divided into two categories. One category was the trading days before specific holiday (when stock market remained close) and the $2^{\text {nd }}$ category was the trading days for the rest of the year. A t-statistic was calculated for differences in the average of returns. Also a descriptive statistics were calculated for all the three indices. The results showed the existence of preholiday effect in all three indices for which study was conducted. The effect was most significant in U.K and Hong Kong indices.

Chong et al (2005) found that average return was more, specifically on the days before a certain holiday than the average returns on non-pre-holidays. Further investigation was performed in order to check the persistence of holiday anomaly over the years for these three markets. The declining pattern was not found in U.K and Hong Kong markets; however a declining pre-holiday effect was witnessed in U.S market particularly in 1990s. Al-Loughani (2005) tested Kuwait Stock Exchange (KSE) for the presence and causes of holiday effect on stock returns. The data used for daily stock index was obtained from Global Investment House. The study was performed for the years 1984-2000. The government announced holidays were taken as holidays which involved the closing of stock market. Al-Loughani (2005) divided the data into two sub periods which included the pre-invasion period from 1984-1990 and the post liberation period from 1993-2000. A comparison was made between returns during the trading days right before specific holiday and the rest of the trading days of year. The results for analysis were obtained by conducting T-statistics, Mann-Whitney test and Kruskal Wallis test.Al-Loughani (2005) observed no noticeable difference between the two sub-periods, which shows the absence of holiday effect in Kuwait Stock Exchange (KSE).In order to determine the presence of any particular pattern surrounding the holidays, further analysis was done using Kruskal Wallis test. The results showed that post-holiday returns were higher as compared to pre-holidays or other trading of the year. The explanation provided by researcher for this reason was that before holiday investors engage in selling and right after the holidays they again develop their investment portfolios.

Cao et al (2009) investigated New Zealand's market for the presence of preholiday effect. Holidays were taken as those days on which stock market remained close and trading did not take place. Cao et al (2009) developed different hypothesis for testing and dissecting pre-holiday anomaly. For the existence of this effect pre-holiday average returns were compared to average returns on all other trading days of the year. Separate evaluation of each holiday was also performed in order to check out that which holiday 
produced the highest returns on the day before it. Different time periods were also examined to check out the consistency of anomaly in order to find out that in which period the anomaly had greater impact. It was also investigated that whether the size of firm plays an important role in pre-holiday effect or not. Lastly, impact of international pre-holiday anomaly on stock returns of New Zealand was also analyzed. The difference in mean returns on pre-holiday and other non-pre-holidays was analyzed for all the firms listed on NZSE 40 and NZSE 50 indices. The data was analyzed from 1967 to 2006 which includes almost 40 years data. All firms on NZSE 10, NZX mid cap and NZX small cap indices were taken into consideration to test the relationship between preholiday effect and firm size.

In order to check out the effect of international pre-holiday effect on New Zealand's pre-holiday returns, the data from 1967 to 2003 was taken for S\&P 500 index. Bid and ask prices of twenty large and twenty small NZ stocks were used to check the consistency of pre-holiday effect. The results showed that the average returns on all other trading days were lower than average returns on pre-holidays. It was also noticed that the ratio of positive returns for all other trading days was lower than the positive returns on pre-holiday days, which rejected the first hypothesis that the ratio of positive returns in pre-holidays and all other trading days is the same. The holidays were Labor Day, Christmas, New Year's Day, Queen's birthday, Easter, ANZAC Day and Waitangi Day. The results were constant with earlier findings that pre-holiday returns were on average much higher than the returns on all other trading days. The day before Christmas showed the highest average returns whereas the day before Easter gave the second highest average returns. The trading day before Labor Day holiday showed the lowest returns. These returns were even less than the average returns on all other trading days. The constancy tests showed that pre-holidays average returns were higher on all other trading days for all the seven periods that were considered.

Wong et al (2006) studied Singapore stock market for pre-holiday effect. The results showed that for the whole sample period taken for pre crisis period the average pre-holiday returns were much higher as compared to average returns on all other trading days of the year. The risk and return trade off was witnessed on pre-holiday days. The results also showed that for post crisis period there was a significant decline in the difference between average pre-holiday returns and rest of the trading day returns, which supports the evidence that calendar anomalies are vanishing in Singapore stock market. Since calendar anomalies have been eliminated from Singapore stock market therefore investors cannot earn abnormal profits showing that Singapore stock market is becoming more and more efficient. Wong et al (2006) also studied Singaporean Stock market for January effect. The data sample was taken the same as for holiday effect. The investigation showed that January average returns were higher than other month's average returns for the pre-crisis period. However, the difference is not very much noticeable. The results also told that average returns for Straits times Index were negative for the whole time period under study, which shows that January anomaly is diminishing in Singapore Stock Market confirming the efficiency of SSM (Singapore Stock Market). Fabozzi et al (1994) provided two possible reasons for explaining the holiday effects. Firstly, their study says that holiday effect can be related to other seasonality which has 
already been discovered like day-of-the-week effect or January effect. For example, holidays can occur on a particular day of the week or in the beginning or end of the month. Lakonishok and Levi (1982) state that explanation of holiday anomaly on stock market and day-of-the-week anomaly is the same, but this result is not in line with observed studies. Therefore it is necessary to study that whether holiday anomaly is caused by other calendar anomalies (Abidin, 2012). Also the high abnormal stock returns are associated with the positive holiday sentiment. Positive holiday sentiment is due to the behavior of the people, the people are looking to the holiday period to enjoy nonworking days. That is why many investors take part in trading (Abidin, 2012). Chan et al (1996) studied Singapore Stock Exchange and Kuala Lumpur Stock Exchange for holiday anomaly. Their investigation showed that there exists a significantly stronger holiday anomaly for cultural holidays as compared to non-cultural holidays i.e. the holidays which have no cultural background. Their study told that cultural holidays had significantly positive abnormal returns for the studied Stock Exchanges.

Yen and Shyy (1993) studied Hong Kong, Japan, Singapore, Taiwan, South Korea, Malaysian Stock Market and all those markets which had Chinese New Year holidays for the Chinese New Year Effect on Asian Stock Market. The researchers studied the sample Stock Exchanges for the period 1976 to 1990. All those countries that had Chinese New Year holidays were taken in this research. The research data was divided into two window periods. The first window was five days before the Chinese New Year holidays and second window used the ten days data after the Chinese New Year holidays. Their study revealed that Chinese New Year Effect has a positive impact on Asian Stock Market and has significant positive higher returns prior to Chinese New Year holidays and stock returns go down to their normal position after the Chinese New Year holidays. Ahmad and Hussain (2001) studied the Kuala Lumpur Stock Exchange for the period 1986-1996. They took the daily average stock returns. The data was divided into two windows. One window was named as prior to Chinese New Year and other window as post Chinese New Year. Ahmad et al (2001) used t-test and z-value for their findings. Their study strongly confirmed the presence of Chinese New Year anomaly. The results suggested that for both the windows the average the daily returns are greater with respect to other event window daily average returns. The results were slightly different, they found that Chinese New Year anomaly took place after the holidays and found that returns are significantly positive. In case of pre-holiday window returns, the results were not that much significant as compared to post-holiday returns.

Brown et al (2002) examined that cultural factors and Chinese Lunar Calendar act as important elements in holiday anomaly that affects the investor's decisions in Asian Market. The researchers also observed that Chinese New Year Festival is one of the most important festivals which represent joy and positivity. This festival usually starts from first day of New Year that is why the stock returns behave abnormally high. Brown et al (1985) also examined Australian stock market for month-of-the-year anomaly. The results suggested the presence of December-January and July-August anomaly effects. The researcher explained the July-August seasonal effect because of June-July tax year. Another study on Chinese New Year holiday anomaly was performed by Lin (1998) who took five years data for Asian-Pacific stock markets. The data was taken between 1991 
and 1997. The study of Lin (1998) revealed that there exists a Chinese New Year Effect as the stock returns before Chinese New Year showed abnormal positive returns except from Nikkei 225 from Japan. Stepanchuk and Wong (1991) studied the Chinese Lunar Calendar Effect, because most of Chinese traditional festivals take place in this year. Their study suggested that abnormal high returns are persistent with Chinese New Year because of the above mentioned reason. Lip (1992) also studied the Chinese New Year Effect and came to know that Chinese lunar calendar plays an important role in business decisions since business management take it into consideration and this role is linked to the superstitions, customs and psychological opinions of the investors. Also they found that Chinese culture is particularly relevant to Chinese festival date. Chen (1988), Liu (1991), Claessens et al (1995), Lee et al (1992 \& 1993) and Tong (1992) all studied Taiwan Stock Exchange for Chinese New Year holidays. Their results strongly confirm the presence of February effect in sample stock exchange which is the effect of Chinese New Year holidays. The results show that average stock returns before and after Chinese New Year holidays are significantly higher. Wong et al (1990) also studied KLSE (Kuala Lumpur Stock Exchange) for Chinese New Year Effect. The research took daily returns of five sectors which included finance, hotels, tins, properties, and plantation. The results revealed that particular anomaly starts one day before Chinese lunar Calendar which showed the presence of pre-holiday effect in Kuala Lumpur Stock Exchange for the taken sample. Another research on Chinese New Year Effect was conducted by Yen et al (2001). The data was taken for the period of 1991 to 2000. The sample included daily stock returns for six Stock Exchanges which are South Korea, Malaysia, Taiwan, Singapore, Hong Kong and Japan. The research findings were that for the entire sample the average returns prior to Chinese New Year holidays and post to Chinese New Year holidays exhibited an increasing trend compared to normal trading days showing the presence of strong Chinese New Year Effect in all six stock exchanges. Similarly Sarath, Azuddin and Diana (2005) also studied Asian-Pacific stock markets for the presence of Chinese New Year anomaly. The study included Indian, Chinese, Hong Kong, Australian, Singaporean, Malaysian, Indonesian, Taiwan, Indonesian and Japanese Stock markets. The results show that Chinese New Year effect is prevalent in four sample countries including Malaysia, Singapore, South Korea and China. Thus confirming the presence of Chinese New Year holidays anomaly.

Vos et al (1993) studied New Zealand's stock market for pre-holiday effect. The researchers took daily stock returns for New Zealand's stock market. The period of study was from 1967 to 1987. Cao et al (2009) as described earlier in this paper extended the work of Vos et al (1993). The results of both researches confirmed the presence of preholiday effect in New Zealand. The research found that pre-holiday average returns are 10.30 times greater than average stock returns on normal trading days. The results were significant at $10 \%$ level. But the study did not confirm the presence of Chinese New Year effect in New Zealand stock market. Zafar, Urooj et al (2010) studied Karachi Stock Exchange (KSE) for holiday and half of the Month Effects. The data was taken for the period of 1991 to 2007. The data was divided into two sub periods based on working days of the week. The first sub-period is taken from November 1991 to February 1997 and second sub period is from March $1^{\text {st }}$ to December $31^{\text {st }}$ 2007.The holidays taken are 
eight holidays which also included Islamic Calendar Holidays. The Islamic Calendar Holidays were first converted into calendar dates and then considered. The holidays taken were March $23^{\text {rd }}$, May $1^{\text {st }}$, August $14^{\text {th }}$, December 25 $5^{\text {th }}$; Ashura holidays (Muharram $10^{\text {th }}$ ), Eid-ul-Fitr holidays (Shawwal $1^{\text {st }}$ ), Eid-ul-Azha (Zil Haj $10^{\text {th }}$ ) and EidMiladunNabi (Rabbi ulAwwal $12^{\text {th }}$ ). For half of the month effect, the month was divided into two halves. The first half of month was considered from $1^{\text {st }}$ to $15^{\text {th }}$ day and all the remaining days of the month were considered as second half of the month. The study used dummy variables and OLS methods. Their results revealed the presence of both holiday and half of the month anomaly. The researchers came to know that pre-holidays returns are higher as compared to post-holidays and regular days returns. For the half of the month effect, the investigation confirmed the presence of this anomaly. In their study they found that the returns of first half of the month are significantly higher than second half of the month returns.

\subsection{Hypothesis}

For testing the holiday anomaly hypothesis for the whole study and t-test are formulated separately. The hypothesis for the overall study is given below and t-test hypothesis is given in t-test explanation.

In order to check holiday anomaly the study has proposed a null hypothesis as follows.

Null Hypothesis (Ho): There is no significant Holiday Effect in Pakistan's Stock Market. Alternate Hypothesis (H1): There is significant Holiday Effect in Pakistan's Stock Market.

\section{Data and Methodology}

The study examines national holiday anomaly for Pakistani Stock Market. The data is considered for ten years i.e. 2004 to 2013. Specifically, Karachi Stock Exchange's 100 index data is used for the study of this particular anomaly. KSE is a market value weighted index and accounts for about $85 \%$ of total market capitalization. The data of daily stock indices of KSE-100 index is taken from "Institute of Management Sciences" financial database which is a leading educational institution of management sciences in Khyber Pakhtunkhwa Pakistan. The data is analyzed for ten years i.e. from February $1^{\text {st }}$ 2004 to December $31^{\text {st }} 2013$. The February 2004 is used as starting period because the first national holiday for which the study is observed lies in February (Kashmir Day). The daily closing value of KSE-100 index is used for calculating average daily stock returns. Stock indices are taken because anomalies are more easily detected in indices as compared to individual shares and also it reflects the trait and performance of overall market. The data is arranged in MS Excel Sheet and the average daily return of stock index is calculated using the formula;

$$
\mathbf{R}_{\mathrm{i}}=\ln \left(\mathbf{P}_{\mathrm{t}} / \mathbf{P}_{\mathrm{t}-1}\right) * \mathbf{1 0 0}
$$

Where $R_{i}$ is the daily stock return, $\ln$ is the natural $\log , \mathrm{P}_{\mathrm{t}}$ is the stock index at time " $\mathrm{t}$ " and $\mathrm{P}_{\mathrm{t}-1}$ is the stock index at time t-1.The Pre-Holidays and Post-Holidays daily average returns are then separated in another excel sheet. In this study the daily stock returns are dependent variable while pre-holidays and post-holidays are independent variables. The pre-holiday is taken as one day before the holiday on which trading took place, if the preceding day before holiday was a non-trading day then last trading day before holiday is considered as pre-holiday. For example in 2004 the last trading day before February 
5th was January 30th, here January $30^{\text {th }}$ is considered as pre-holiday instead of February $4^{\text {th }}$ and similar is the case for whole data. The post-holiday days are taken as those days which were following the holiday and trading took place on that day. If the day right after the holiday was not a trading day then the first trading day after holiday is taken as postholiday day i.e. in 2004, May $4^{\text {th }}$ is considered as the post-holiday for Labor Day because trading day after Labor Day was May $4^{\text {th }}$ instead of May 2 nd. Similarly if the pre-holiday and post-holiday days had weekend holidays before or after them respectively, the last trading day before national holiday is considered as pre-holiday and first trading day after holiday is considered as post-holiday. The study tests the holiday anomaly for six national holidays. The list of national holidays is taken from officeholidays.com. The days on which KSE remained close is taken from KSE data portal. The Karachi Stock Exchange observes many calendar holidays which also contains Islamic Calendar Holidays like Eid-ul-Fitr, Eid-ul-Azha, EidMilad-un-Nabi and Ashura Muharram etc and many other holidays but this study does not include Islamic Calendar Holidays and other holidays rather it focuses on six national holidays. The study also do not consider weekend holidays. The six national holidays taken by the study are given in table below.

\begin{tabular}{|ccc|}
\hline \multicolumn{3}{|c|}{ Table 1: Studied Holidays } \\
\hline S.No & Date & Holiday Description \\
\hline 1 & February 5th & Kashmir Day \\
2 & March 23rd & Pakistan Day \\
3 & May Ist & Labor Day \\
4 & August 14th & Independence Day \\
5 & November 9th & Iqbal Day \\
6 & December 25th Quaid-e-Azam Day/Christmas \\
\hline
\end{tabular}

For the purpose of analyzing the data in depth, the study also examined national holiday anomaly for individual year as well as for whole sample period. Every national holiday is also observed separately to check whether any specific holiday has significant effect on Stock Market or not. The study of individual holiday separately enables us to understand that which holiday has more anomalous behavior as compared to other holidays. For the existence of holiday anomaly the study used t-test: Paired Two Samples for Means. The above mentioned t-test is used to study holiday anomaly for individual year, individual holiday and whole sample period. The study also calculates Descriptive Statistics and Correlation for the whole sample period.

\subsection{T-Test}

The t-test is a type of inferential statistics which is used to determine whether there is a statistically significant difference between the Means of two groups or not. This test is used when the Means of two groups are compared. It is especially very appropriate when the analysis is done for two set of groups. In all inferential statistics we have a dependent variable which we assume to have a normal distribution. 
For the existence of normal distribution, a particular outcome of probability is recognized. Before the collection of data a particular level of significance is recognized which we are willing to accept. This level of significance is commonly known as (level of significance or alpha level or $p$ ). Most of the times " $p<0.05$ " value is used. The 0.05 value of " $p$ " shows that 5 times out of hundred, the study will find a statistically significant difference between the Means even if the difference is by chance. A particular formula is used for calculating test statistics. The value of t-statistics is then compared with a critical value which is given in a table. The comparison is done to check out the level of significance that whether the sample results fall within the acceptable level that we have assumed or not. Nowadays there are certain computer Soft wares like MS Office (MS, Excel), SPSS etc which calculate t-stat for sample and the result provided by them also show the exact probability level. The t-test is conceptually the extension of z-scores which provides the standard units for the difference between Means of two groups. The value of t-test enables a researcher to say with certain degree of confidence that the Mean difference between the two groups is either by chance or the difference is actually present in the taken sample. The one-way Analysis of Variance (ANOVA), a form of regression analysis and t-test are mathematically equal and would give similar outcomes. The formula used for calculating the value of t-test is;

$$
t-\text { test }=\frac{\overline{\mathbf{X}}_{\mathbf{a}}-\overline{\mathbf{X}}_{\mathrm{b}}}{\sqrt{\frac{\operatorname{var}_{\mathbf{a}}}{\mathbf{n}_{\mathrm{a}}}+\frac{\mathbf{v a r}_{\mathbf{b}}}{\mathbf{n}_{\mathrm{b}}}}}
$$

In the above equation $\bar{X}_{\mathrm{a}}$ represents the Mean of first variable, $\bar{X}_{\mathrm{b}}$ shows the Mean of second variable, $\operatorname{var}_{\mathrm{a}}$ is the variance of first variable and $v \mathrm{var}_{\mathrm{b}}$ is the variance of second variable. Also $\mathrm{n}_{\mathrm{a}}$ represents the number of first variable and $\mathrm{nb}$ represents the number of second variable. The value of $t$ is positive if the Mean of first variable is greater and negative if the Mean of first variable is less than the Mean of second variable.

\subsubsection{Method used for finding national holiday anomaly

$$
t-\text { test }=\frac{\overline{\mathbf{X}}_{\text {pre }}-\overline{\mathbf{X}}_{\text {post }}}{\sqrt{\frac{\text { var }_{\text {pre }}}{\mathbf{n}_{\text {pre }}}+\frac{\text { var }_{\text {post }}}{n_{\text {post }}}}}
$$

Formula of t-test used by the study for Pre-Holiday and Post-Holiday Anomaly The above model is used by the study for finding the Pre and Post National Holiday Anomaly. In the above equation $\overline{\mathrm{X}}_{\text {pre }}$ represents the Mean return of pre-holidays, $\overline{\mathrm{X}}_{\text {post }}$ represents the Mean return of post-holidays, var ${ }_{p r e}$ is the variance of pre-holidays, $v a r_{\text {post }}$ is the variance of post holidays, $\mathrm{n}_{\text {pre }}$ is the number of pre-holiday observations and $\mathrm{n}_{\text {post }}$ is the number of post-holiday observations. The results of t-test are given in table 3 in empirical findings chapter. 


\subsubsection{T-Test Hypothesis}

The study has formulated the hypothesis for t-test as follows;

Null Hypothesis: There is no significant mean difference between average returns of preholidays and post-holidays or the mean is equal.

\section{i.e. $P>0.05$, t-stat $<$ t-critical}

Alternate Hypothesis: There is significant mean difference between average returns of pre-holidays and post-holidays or the mean is unequal.

\section{i.e. $P<0.05$, t-stat $>$ t-critical}

In order to reject null hypothesis the P-value must be less than 0.05 . If the P-value is greater than 0.05 then the study cannot reject null hypothesis which means that there is no significant mean difference between pre and post-holidays returns. Also for the rejection of null hypothesis the value of t-stat must be greater than t-critical. If the value of t-stat > t-critical then we can reject Ho otherwise not.

\section{Empirical Findings}

This section contains the findings of the study. The study conducted t-test, correlation test and descriptive statistics. The results of all these tests and their interpretation are given in this section.

\subsection{Descriptive Statistics}

Descriptive statistics is a statistical tool used for showing the basic features of data taken in a study. Descriptive statistics present a simple summary of taken sample. They provide a base for quantitative analysis of data. Descriptive statistics and inferential statistics are two different things. Inferential statistics enable us to reach conclusions beyond the data available, whereas Descriptive statistics simply explain what is shown by data and what is included in the data. Descriptive statistics simply shows what is going on in the data. Descriptive statistics ensure presentation of quantitative data in a manageable form. During the process of research a considerable amount of measures are taken, descriptive statistics enables us to present large amount of data in a sensible and simplified manner. Every set of descriptive statistics is a summary of large sample of data. The descriptive statistics include a number of techniques which are used for the representation of whole data. These techniques include Mean, Median, Mode, Range, Variance, Standard Deviation etc. Mean is the sum of all numbers in a data divided by number of observations. Median is the middle number of sample. Mode is the largest number in data sample. Range is obtained by subtracting the largest number of sample from smallest number of sample. Variance is the sum of squares of numbers subtracted from mean divided by one less than total number of observations whereas Standard Deviation is the square root of variance. The Descriptive Statistics for Pre-holidays and Post-holidays for the 2004 to 2013 period are mentioned in Table 2.1 and Table 2.2 respectively; 
Table 2.1 Pre-Holiday

\begin{tabular}{|lr|}
\hline Mean & 0.08745 \\
Median & 0.16452 \\
Standard Deviation & 1.33149 \\
Sample Variance & 1.77287 \\
Range & 7.22759 \\
Minimum & 4.49130 \\
Maximum & 2.73628 \\
Count & 60 \\
\hline
\end{tabular}

Table 2.1 shows the descriptive statistics of the daily returns of KSE-100 index for pre-holidays which includes Mean, Median, Standard deviation and No. of observations for the pre-holidays from 2004 to 2013 period. The table shows that over the sample period, mean of pre-holidays for the taken sample is 0.0876 which means that mean average return for pre-holiday is 0.087 representing $8.7 \%$ daily average returns for pre-holidays. This statistics mean that for all the national holidays the average stock returns before one day of national holiday is $8.7 \%$ for the whole sample period. The average Mean stock returns of pre-holidays for the entire period are positive. The lowest pre-holiday return for the sample period is -4.49 whereas 2.74 is recorded as the highest pre-holiday return. The standard deviation of pre-holidays is 1.33 . The No. of observations is 60 because the study took six national holidays for ten years in Pakistan.

Table 2.2 Post Holiday

\begin{tabular}{|lr|}
\hline Mean & 0.05510 \\
\hline Median & 0.17180 \\
Standard Deviation & 1.79416 \\
Sample Variance & 3.21901 \\
Range & 13.08501 \\
Minimum & 8.81436 \\
Maximum & 4.27065 \\
Count & 60
\end{tabular}

Table 2.2 shows the descriptive statistics for daily returns of KSE-100 index for post-holidays. The data under study was from 2004 to2013. The table contains descriptive statistics including Mean, Standard Error, Median, Standard Deviation, Variance, Range, and No. of observations for post-holidays for the data sample. The table shows that the average returns for post-holidays are recorded as 0.055 which means that daily average post-holiday return is $5.5 \%$. This means that first day of trading after holiday has an average return of 5.5\%. The average return for the whole sample period is positive. Comparing Mean returns for both pre-holidays and post-holidays the study find that average pre-holidays returns (0.087) are slightly greater than average post-holiday returns $(0.055)$ with a difference of 0.032 . However, the difference between the Mean returns is not so significant. The Median of post-holidays is 0.1718 which represents the middle value of the sample. The range of post-holidays is 13.085 . The minimum value of post-holidays recorded is -8.814 while the maximum value is 4.270 . The Variance of 
sample is 3.219 with Standard Deviation of 1.794 .

\subsection{Correlation}

Correlation is a statistical technique which shows that to what extent a pair of variables is related to each other. It is a combination of two words Co meaning "together" and relation, therefore it is obvious from the definition that it shows the relationship between two or more variables. Correlation enables researchers to better understand the data set. The result of correlation co-efficient is usually known as correlation coefficient denoted by "r". It is also known as Pearson Coefficient. This coefficient is commonly used for the calculation of correlation between two variables. The value of correlation coefficient ranges from -1 to +1 . If the value of $r$ is close to -1 or +1 it means that there is a strong correlation between two variables. If $r$ is 0 , it suggests that there is no relationship between the two variables. A positive "r" value shows that an increase in one variable causes an increase in another variable as well and a negative $r$ value reveals that as one variable increases it causes a decrease in another variable often known as "inverse" correlation. Correlation coefficient is generally reported between -1 and +1 . When we square the value of " $r$ " it becomes easier to understand. The square of correlation coefficient shows the percentage variation in one variable regard to another variable. In the table below is the correlation between pre-holiday and post-holiday returns for the taken sample period.

Table 3: Correlation between Pre-Holiday and Post-Holiday

\begin{tabular}{|lcr|}
\hline Correlation & Post Holiday & Pre-Holiday \\
\hline $\begin{array}{l}\text { Post-Holiday } 1 \\
\text { Pre-Holiday }\end{array}$ & 0.39125 & 1 \\
\hline
\end{tabular}

This study has also conducted a correlation test in order to check whether both these variables (pre-holiday returns and post-holiday returns) have a relationship with each other or not. The correlation test was performed that a variation in one variable causes how much variation in another variable. The correlation test of pre-holidays and post-holidays was performed using MS-Office "Excel". The results of correlation are shown in table 2 . The table 2 shows that correlation coefficient between pre-holidays and post-holidays for the sample period is recorded as $0.39 \%$. This means that there is a weak to medium positive linear relationship between returns of pre-holidays and post-holidays. To interpret the results in exact manner, we can say that a $100 \%$ increase in the returns of pre-holidays brings about a 39\% increase in post-holidays returns which shows that both pre-holidays and post-holidays returns move positively with each other. The pre-holiday returns have a positive relationship with post-holiday returns and that both returns move along positively. 
Table 4.1: t-Test: Paired Two Sample for Means

\begin{tabular}{|lrr|}
\hline & Pre-Holiday & Post-Holiday \\
\hline Mean & 0.08745 & 0.0551 \\
Variance & 1.77287 & 3.21901 \\
Observations & 60 & 60 \\
\hline Pearson Correlation & 0.39125 & \\
Hypothesized Mean Difference & 0 & \\
Df & 59 & \\
t Stat & 0.14182 & \\
P $(\mathrm{T}<=t)$ one-tail & 0.44385 & \\
t Critical one-tail & 1.67109 & \\
P $(\mathbf{T}<=t)$ two-tail & $\mathbf{0 . 8 8 7 7}$ & \\
t Critical two-tail & 2.00099 & \\
\hline
\end{tabular}

\subsection{T-Test Results}

Table 4.1 displays the t-test results conducted by the study for the presence of national holiday anomaly in KSE 100-index for the period of study. It is quite obvious from the table that there is no significant Mean difference between the returns of preholidays and post-holidays. The Mean of both variables are already discussed in detail. The table also shows that p-value is 0.88 which is quite greater than 0.05 , which means that on the basis of this result the study cannot reject the null hypothesis, which states that there is a no significant Mean difference between pre-holidays and post-holidays returns. For the rejection of Null Hypothesis it was important that the p-value should have been less than $0.05(\mathrm{p}<0.05)$ which is not the case here. Also looking at the value of t-stat one can easily see that $t$-stat value is less than t-critical $(0.14182<2.00099)$ which again confirms that there is no significant Mean difference between pre-holidays and postholidays. Therefore, based on these results the study cannot reject Null Hypothesis, which means that the National Holiday Anomaly does not exist in Pakistani Stock Market, specifically in KSE-100 index for the studied period (2004-2013). Therefore the evidence provided by this study suggests that Pakistani Stock Market is an Efficient Stock Market with respect to national holidays for the taken sample period where the securities are fairly priced and no one can outperform the market with respect to National Holidays.

The results of t-test are not in conformity with previous literature. Zafar et al (2012) studied holiday effect in Pakistani Stock Market. Their results confirmed the presence of holiday anomaly in Pakistani Stock Market. The difference in results of this study and Zafar et al (2012) may be due to different types of holidays taken by the studies. Also another factor can be sample periods taken. Zafar et al (2012) studied holiday anomaly from 1991-2007 whereas this study tested data for 2004 to 2013. 
Zafar et al (2012) in their study also included Islamic Calendar Holidays, while this paper investigates holiday anomaly for six national holidays and does not consider Islamic Calendar Holidays. These may be the reasons for the change in results. One possible explanation for the absence of National Holiday Anomaly is that in modern days the national holidays are not celebrated in that way as were in past. The February $5^{\text {th }}$ is Kashmir Day, which is solidarity with the people of Kashmir. The investor does not think that this day can have an impact on stock market. Similarly March $23^{\text {rd }}$, May $1^{\text {st }}$, November $9^{\text {th }}$ and December $25^{\text {th }}$ are also such holidays which are not celebrated with great interest and also no such activity is surrounded by these holidays which can affect the decision process of investors. August $14^{\text {th }}$ is also included in this study but it too doesn't seem to have a great impact on Stock Market. The Islamic Calendar Holidays have more impact on Pakistani Stock Market because it is obvious that in Ashura's Days (Muharrum $9^{\text {th }} \& 10^{\text {th }}$ ) the law and order situation is very critical and investors want to sell their stocks because they fear that the prices may come down. Similarly in Eid-ulAzha (Zul-Haj 10th) the investors want to sell their stocks because every Muslim needs money to perform slaughter. This is why the results shown by this study elucidates the absence of national holiday anomaly in Pakistan's stock market.

Table 4.2: T-Test Year wise Comparison of Means for Pre-Holidays and Post-Holidays

\begin{tabular}{|ccccc|}
\hline S.No & Year & $\begin{array}{c}\text { T-Test Results (P-value) } \\
\text { Two Tail }\end{array}$ & $\begin{array}{c}\text { T-Stat } \\
\text { Value }\end{array}$ & $\begin{array}{c}\text { T-Critical } \\
\text { Value }\end{array}$ \\
\hline 1 & 2004 & 0.83986 & -0.0213 & 2.57058 \\
2 & 2005 & 0.2272 & 1.37619 & 2.57058 \\
3 & 2006 & 0.58306 & -0.5864 & 2.57058 \\
4 & 2007 & 0.69614 & -0.4138 & 2.57058 \\
5 & 2008 & 0.147 & -1.715 & 2.57058 \\
6 & 2009 & 0.86334 & -0.1812 & 2.57058 \\
7 & 2010 & 0.4214 & 0.87541 & 2.57058 \\
8 & 2011 & 0.03159 & 2.95794 & 2.57058 \\
9 & 2012 & 0.42294 & -0.8723 & 2.57058 \\
10 & 2013 & 0.3924 & 0.93565 & 2.57058 \\
11 & $2004-$ & 0.8877 & 0.14182 & 2.00099 \\
\hline
\end{tabular}

In order to study the anomaly in detail t-test was performed for every year of sample period and for each individual holiday as well. The results of each year and individual holiday separately are given in table 4.2 and 4.3 respectively. The value of tcritical for each individual year is same i.e. 2.57058 and different for the whole sample period 2.00099. The t-critical value is same for each individual holiday as well i.e. 2.26216. The study of individual years shows that for most of the years the value of $p$ is 
insignificant i.e. greater than 0.05 and also t-stat is less than t-critical. The year 2011 is an exception which has a significant value where the p-value is 0.03159 which is less than 0.05 and t-stat (2.95794) is also greater than t-critical (2.57058) showing the presence of National holiday anomaly in 2011. For every other year the p-value is insignificant revealing the absence of national holiday anomaly on year wise basis except for 2011 .

Table 4.3: T-Test Results for Individual National Holiday from 2004 to 2013

\begin{tabular}{|ccccccc|}
\hline Holiday & 5-Feb & 23-Mar & 1-May & 14-Aug & 9-Nov & 25-Dec \\
\hline $\begin{array}{c}\text { P-value } \\
\text { Two Tail }\end{array}$ & 0.57085 & 0.49224 & 0.97241 & 0.77804 & 0.64649 & 0.65189 \\
T-Stat & 0.58821 & -0.7159 & -0.0335 & 0.29047 & 0.47442 & 0.46657 \\
T- & 2.26216 & 2.26216 & 2.26216 & 2.26216 & 2.26216 & 2.26216 \\
Critical & & & & & & \\
\hline
\end{tabular}

Each national holiday was also studied separately using t-test paired two samples for Means in order to check that whether any specific holiday has significant value or not. The p-values given by t-test for February $5^{\text {th }}$, March $23^{\text {rd }}$, May $1^{\text {st }}$, August $14^{\text {th }}$, November $9^{\text {th }}$, and December $25^{\text {th }}$ are $0.57085,0.49224,0.97241,0.77804,0.64649$ and 0.65189 respectively. It is quite obvious that there is no significant $p$-value. All the values of $p$ are greater than 0.05 which indicates insignificance. This means that no national holiday shows significance which again confirms the results of earlier study that national holiday anomaly is not present in Pakistani Stock Market for the taken sample period based on the evidence provided by this investigation. The results for individual holidays also suggest that there is no particular holiday which shows sign of holiday anomaly. This show that national holiday anomaly is not present in Pakistani Stock Market for the sample period neither on individual holiday basis nor for the entire studied period. The study of each individual year also does not show the presence of national holiday anomaly except for 2011.

\section{Conclusion}

This study analyzed Pakistani Stock Market specifically Karachi Stock Exchange (KSE) 100 index for National Holiday Anomaly. The focus of this study is to determine the presence of National Holiday Anomaly in Pakistani Stock Market. For this purpose the pre-holidays and post-holidays daily average stock returns of six national holidays are considered for ten years data. The sample period taken is from 2004 to 2013 . The study has employed t-test Paired Two Sample for Means for the presence of holiday anomaly. The analysis of holiday anomaly revealed that there is no significant difference between the returns of pre-holidays and post-holidays for the taken sample period which is in contrast to the findings of Zafar et al (2012) which found significant pre-holiday returns. The change in result may be due to the different types of holidays considered by both studies and/or different data sets. The investigation also examined pre-holidays and postholidays returns for each individual holiday and individual year as well. The results for both individual holiday and individual year also do not show any significant Mean 
difference between both variables. The study explains this phenomenon as the lack of importance given to these national holidays by investors, as there is no particular activity surrounded by these national holidays which the investors consider can have an impact on their investment decisions. Therefore based on the evidence provided by this study, the investigation can say that Pakistani Stock Market is an efficient stock market with regards to the national holidays for the taken sample period. However, there are certain other factors which are not considered by the study. The results of this study should not be considered as a reflection of the whole Pakistani Stock Market. This study contributes to the existing evidence on holiday effect and provides fresh insights about Pakistani Stock Market. Overall this study contributes to our understanding of efficiency of Pakistani Stock Market.

\section{References}

Abidin, R. \& Chen. (2012). Determinants of ownership structure and performance of seasoned equity off springs: Evidence from Chinese Stock Market. .International Journal of Managerial Finance, 8, (4), 304-331.

Agrawal, A. \& Tandon, K. (1994). Anomalies or Illusions? Evidence from Stock Markets in Eighteen Countries. Journal of International Money and Finance, 13(1): 83106.

Ahmad, Z., \& Hussain, S. (2001). KLSE Long Run Overreaction and the ChineseNew Year Effect. Journal of business finance \& accounting, 28(12), 63-105.

Al-Loughani, N. E., Al-Saad, K. M., \& Ali, M.M. (2005). The Holiday Effect and Stock Returns in the Kuwait Stock Exchange. Journal of Global Competitiveness, 13(1\&2), 8191.

Ariel, R. A. (1990). High Stock Returns before Holidays: Existence and Evidence on Possible Causes. Journal of Finance, 45(5): 1611-1626.

Bashir, T., Ilyas, M. \& Furrukh, A. (2011). Testing Weak Form-Efficiency of Pakistani Stock Markets An Empirical Study in Banking Sector. European Journal of Economics, Finance and Administrative Sciences, 31, 160-175.

Brown, P., Chua, A., \& Mitchell, J. (2002). The influence of Cultural factors on price clustering: Evidence from Asia-Pacific stock markets. Pacific-Basin Finance Journal, 10, 307-332.

Cadsby, C. B. \& Ratner, M. (1992). Turn-of-month and Pre-Holiday Effects on Stock Returns: Some International Evidence. Journal of Banking and Finance. 16: 497509.

Cao, X., Premachandra, I.M., Bharba, G.S. \& Tang, Y.P. (2009). Firm size and the preholiday effect in New Zealand. International Research Journal of Finance and Economics, 32, pp.171 -187.

Chan, W. M., Khathavit, A., \& Hugh, T. (1996).seasonality and cultural influences on four Asian stock markets. Asia Pacific Journal of Management, 13(2), 1-24.

Chen, Y. F. (1988). The study of relationship between stock return and firm size: Empirical test of listed companies in Taiwan. Unpublished Masters Dissertation. Chung Yuan Christian University, Taiwan.

Chong, R., Hudson, R., Keasey, K., \& Littler, K. (2005). Pre-holiday effects: International evidence on the decline and reversel of a stock market anomaly. 
Journal of International Money and Finance, 24, 1226-1236.

Claessens, S., Dasgupta, S., \& Glen, J. (1995). Return behavior in emerging stock markets. The World Bank Economic Review, 9(1), 131-151.

Correlation (2012). Retrieved November 11, 2014, fromwww.surveysystem.com/correlation.htm. orrelation (2014). Retrieved November 11, 2014, from www.mathsisfun.com/data/correlation.html.

Del Siegle (n.d). Principles and Methods in Educational Research.RetrievedNovember 09, 2014, from www.gifted.uconn.edu/siegle/research/t-test/t-test.html .

Fabozzi, K.M \&. Briley, A, (1994). Holiday Trading in Future Markets. The Journal of Finance, XLIX (1), 307-324.

Karachi Stock Exchange Limited (2014). KSE Holiday Calendar. Retrieved October 28, 2014, from dps.kse.com.pk.

KSE Annual Report (2011).Karachi Stock Exchange. Retrieved on October 12, 2014 from www.kse.com.pk.

KSE-100 Index Daily 1990-2014(n.d).KSE 100 index Data.Retrieved October 28, 2014, fromwww.opendoors.pk/Home-Page2/data/karachi-stock-exchange-kse-data .

Lakonishok, J., \& Levi, M. (1982). Weekend effects on stock returns: a note. The Journal of Finance, 37(3), 883-889.

Lakonishok, J. \& Smidt, S. (1988). Are seasonal anomalies real? A ninety-year perspective, The Review of Financial Studies, 1 (4), pp. 403-425.

Lee, C. F., Yen, G., \& Chang, C. (1992). Informational efficiency of capital market revisited: Anomalous evidence from a refined test. Advanced in Quantitative Analysis of Finance and Accounting, 2, 366-376.

Lim, S. Y., Mun Ho, C., \& Dollery, B. (2010). An empirical analysis of calendar anomalies in the Malaysian stock market. Applied Financial Economics, 20, (3),255-264.

Liao, Chang, Cheng, Shih \& Chia (2004). Employee relationship and knowledge sharing: a case study of a Taiwanese finance and securities firm. Knowledge Management Research \& Practice, 2, (1), 24-34.

Lin, W.Q. (1998). The Chinese New Year effect on major Asian-Pacific stock markets: Empirical evidence from 1991 to 1996.Working Paper, Taiwan.

Lip, E. (1992). Chinese numbers: Significance, Symbolism and traditions. Singapore: Times Books International

Liu, L. Y. (1991). The study of January effect and its causes in Taiwan stock markets. Unpublished Masters Dissertation. Chung Yuan Christian University, Taiwan.

Marrett, G. J. \& Worthington, A. C. (2007). An Empirical Note on the Holiday Effect in the Australian Stock Market, Working Paper, School of Accounting and Finance, University of Wollongong, Wollongong.

McGuinness, P.B. (2005). A re-examination of the holiday effect in the stock returns: the case of Hong Kong, Applied Financial Economics, 15, pp. 1107-1123.

Muhammad, N., \& Rahman, N. D. (2010). Efficient Market Hypothesis and Market Anomaly: Substantiation from Day-of-the Week Effect of Malaysian Exchange. International Journal of Economics \& Finance, 2(2), 35-42.

National and regional public holidays of Pakistan (n.d).Retrieved October 28, 2014, from 
www.officeholidays.com/countries/pakistan/ .

Rozeff, M. S., \& William R. K. (1976). Capital Market Seasonality: The Case of Stock Market Returns. Journal of Financial Economics, Vol. 3, pp. 376- 402.

Shahid, M. N., \& Mehmood, Z. (2015). Calendar Anomalies in Stock Market: A Case of KSE 100 Index. International Journal of African and Asian Studies, 7, 16-23.

Stepanchuk, C., \& Wong, C., (1991). Moon cakes and Hungry Ghosts: Festival of China. China Books and Periodicals, San Francisco.

Vergin RC, \& McGinnis, J. (1999). Revisiting the Holiday Effect: is it on holiday? Applied Financial Economics. 9(5): 477-482.

Vos, E., Cheung, J., \& Bishop, D. (1993). Pre-holiday returns in the New Zealand share market. Accounting Research Journal, 6, 21-26.

William, M. K. T. (2006). Descriptive Statistics. Retrieved November 09, 2014, from www.socialresearchmethods.net/kb/statdesc.php.

William, M. K. T. (2006). The T-Test. Retrieved November 09, 2014, from www.socialresearchmethods.net/kb/stat_t.php .

Wong, P. L., Neoh, S. K., Lee, H. K., \& Thong, S. T. (1990). Seasonality in the Malaysian stock market. Asia Pacific Journal of Management, 7(Special Issue), 43-62.

Wong, W. K., Agarwal, A., \& Wong, N.T. (2006). The disappearing Calendar Anomalies in the Singapore stock market. The Lahore Journal of Economics, 11(2), 123139.

Yakob, N. A. Diana, B. \& Sarath, D. (2005). Seasonality in the Asia Pacific Stock Markets. Journal of Assets Management, 6, 298-318.

Yen, G., Lee, C. F., Chen, C. L., \& Lin, C. W. (2001). On the Chinese Lunar New Year effect in six Asian stock markets: An empirical Analysis (1991-2000). Review of Pacific Basin Financial Markets and Policies, 4(4), 463-478.

Yen, G., \& Shyy, G. (1993).Chinese New Year effect in Asian stock markets. NTU Management Review, 4(1), 417-436.

Zafar, N., Urooj, S. F., Chughtai, S., \& Amjad, S. (2012). Calendar Anomalies: Case of Karachi Stock Exchange. African Journal of Business Management, 6(24), 72617271. 